\title{
FACTORS INFLUENCING THE TRUST OF YOUNG CUSTOMERS WHILE USING E-COMMERCE WEBSITES
}

\author{
Lê Đình Minh Trí, MBA, Lecturer at International University, VNU HCMC \\ Ṽ̃ Bảo Lộc, International University, VNU HCMC
}

\begin{abstract}
Internet shopping is now enjoying its prevalence and rapid development in Vietnam. One of factors could be high barrier for this development is consumers' trust. Lack of trust on websites is a primary reason why many web users do not shop online. This quantitative study is to identify the factors influencing consumers' trust on websites from the perspective of youths. The proposed model, in this study, is empirically tested using a questionnaire-based field study. A survey of 325 online shoppers has been conducted. Regression analysis is used to test the hypothesis derived from the framework. The result indicates that consumers' trust on Internet shopping is built on the high level of customers' perception about the store and company reputation; system quality, and service quality of the website; as well as the effectiveness of third party recognition. Implications and suggestions for further studies were also provided in this study.
\end{abstract}

Keywords: customer trust, e-commerce, internet marketing

\section{INTRODUCTION}

Recently, the Internet population has been exploding. There has been a steady increase in both internet users, the number of websites in Vietnam as well as the technical resources to provide internet connections are constantly expanding. According to Vietnam NetCitizens Report (2011), Internet penetration in Vietnam was at $31 \%$ by the end of 2010 , which is similar to countries like China, Philippines and Thailand. Furthermore, Vietnam has been seen as a more rapid growth of the internet over the last few years than most of other countries in the region and is the one of the fastest growing internet countries in the world.

Internet has opened up tremendous business opportunities for its users. Customers are significantly more likely to purchase products from e-stores than from traditional retail outlets; that is, e-stores are "sticky". Shopping online has become a common channel for people in many developed countries, such as e-commerce sales account for $\$ 9,849$ million or $1.3 \%$ of all sales in the US (US Department of Commerce, 2009).

Even though the rising number of online shopping websites definitely raises consumer awareness towards internet retailing, there were also many factors hindering the growth of this channel. These factors are closely related to the attitude of trust from customer towards the online shopping. According to the survey made by Cimigo Netcitizens (2011), only $13 \%$ of the respondents think that it is safe to buy products online. Lack of trust has been one of the most frequently cited reasons for consumers not purchasing from Internet vendors.

Many researchers have stated that trust is a critical factor in stimulating 
the customer's purchase intention over the Internet. According to Teo and Liu (2007), understanding consumer trust's antecedents and consequences will help online firms to know the important factors affecting trust and then they will have the appropriate measures to facilitate trust. Moreover, according to Cimigo Netcitizens (2011), majority of online shopping customers is young people. Young people are very active online, using Internet longer and for more activities. Many studies also take student as the sample in order to investigate about the e-shopping model. Therefore, this study aims to identify main factors affecting the young Vietnamese customer's trust in purchasing products or service from the online retailers. From that, the managers can understand the importance of trust and its effect on online buying behavior.

\section{THEORETICAL BACKGROUND}

\section{AND METHODOLOGY}

According to the Organization for Economic Co-operation and Development (OECD) (1999), e-commerce refers to the "sale or purchase of goods or services, whether between businesses, households, individuals, governments, and other public or private organizations, conducted over computer-mediated networks. The goods and services are ordered over those networks, but the payment and the ultimate delivery of the good or service may be conducted on or off-line." There is also a narrow definition which restricts the "computer mediated networks" to the Internet.

The concept of trust is explained in different ways by different disciplines. The economists define it as trusting the institutions and their accounts while the psychologists explain it with the reliable and unreliable behavior of the individual and the sociologists use it as the reliable, fair and ethical behavior in interpersonal relations (Milligan, 2003 cited in Abdullah, Y. \& Ceren, G.A. , 2009).

Online trust or trust on the Internet differs from offline trust in many ways. According to Jarvenpaa et al. (2000), the online and offline commerce differ in some key aspects, including: (1) The parties involved may interact across different times and locations: rules and regulations may vary across these zones; (2) Less data control during and following its transfer; (3) Partners may be more likely to not know each other in an online environment, compared to an offline environment; (4) Lower barriers to entry and exit: online vendors may be considered "fly-by-night" as there are few assurances that they will stay in business for some time; (5) The absence of the physical elements; (6) The decreased human/social element, resulting in lower social presence. On the other words, online purchase involves higher degree of uncertainty and risk compared to offline commerce.

Previous studies have identified a number of factors that can potentially influence consumers' trust in online companies, such as perceived technology (including perceived usefulness, perceived ease of use, and perceived enjoyment of technology), perceived security and privacy, marketing orientation, third party certification, legal framework, website appeal, company competency (including perceived company size, perceived good reputation, perceived willingness to customize, and perceived interaction) and so on.

\section{a) Perceptions about companies}

Perceived Size is defined a seller's size as its overall size and market share position (Doney and Cannon, 1997). Size of the store has been proved in previous studies that it is one of the bases used by customers to form their impressions 
regarding the store's trustworthiness.

Perceived Reputation, like size, is conceptualized as the consumer's perception of a store's reputation, where "reputation" is defined as the extent to which buyers believe a selling organization is professional competent or honest and concerned about its customers (Doney and Cannon, 1997).

\section{b) Perceptions about the website quality}

Perceived System Quality is manifest in a website system's overall performance and can be measured by customer perceived degree of user friendliness in shopping at an online retailer. In the other words, system quality refers to the measurement of the information processing system (Negasha et al., 2003).

Perceived Information Quality refers to the quality of information that an information system provides. In the context of online stores, information quality can be defined as the customers' general perception of collective content quality of online store. Previous studies found that information quality affect factors that related to online store success, such as user satisfaction, intention to use and system usage (DeLone and McLean, 2003).

Perceived Service Quality is defined as the extent to which a website facilitates efficient and effective shopping, purchasing, and product delivery. Service quality for a web-based company depends on its provision of multiple communication mechanisms for accepting user complaints and their timely resolution; it also involves assisting users in being effective, suggesting complementary products or service; and jointly solving problems.

\section{c) External environment factors}

Third Party Recognition is defined as any third-party marks, logos, pictures, or symbols that is presented in an effort to dispel consumers' concerns about Internet security and privacy and, therefore, expected to increase firm-specific trust levels in Vietnam market. Third-party authentication seals are another way for e-commerce sites to demonstrate their trustworthiness.

Legal Framework refers to the law and code of practice established by the government to protect Internet shoppers during electronic transactions. It is expected that a high efficiency of legal structure may directly affect to the formation of customer's trust when they participate in the online transactions.

\section{d) Customers' Trust}

Trust is a psychological condition comprising the intention to accept vulnerability based on positive expectations of another party's intention or behavior, in interdependent and risky environment (Rousseau, 1998). According to Lewis and Weigert (1985), trust is identified as the understanding of risky course of action on the confident expectation that all persons involved in the action will act competently and dutifully. Briefly, people are willing to take risk when they participate in the online transactions with the beliefs that this organization is trustworthy and responsible in their business.

Based on the literature review, a conceptual framework has been designed to study the influence of consumer perceptions and external environment factors on consumer's trust. Specifically, this model will help to explores the relationship between perceptions about the company (including perceived size and perceived reputation), perceptions about the website quality (including system quality, information quality, and service quality), external environment factors 
(including third party recognition and legal framework) and consumer's trust when using e-commerce websites.

H1: Perceived size is positively related to consumers' trust on e-commerce websites.

$\mathrm{H} 2$ : Perceived reputation is positively related to consumers' trust on e-commerce websites.

H3: Perceived system quality is positively related to consumers' trust on e-commerce websites.
H4: Perceived information quality is positively related to consumers' trust on e-commerce websites.

H5: Perceived service quality is positively related to consumers' trust on e-commerce websites.

H6: The perceived effectiveness of third party recognition is positively related to consumers' trust on e-commerce websites.

H7: The perceived effectiveness of legal framework is positively related to consumers' trust on e-commerce websites.

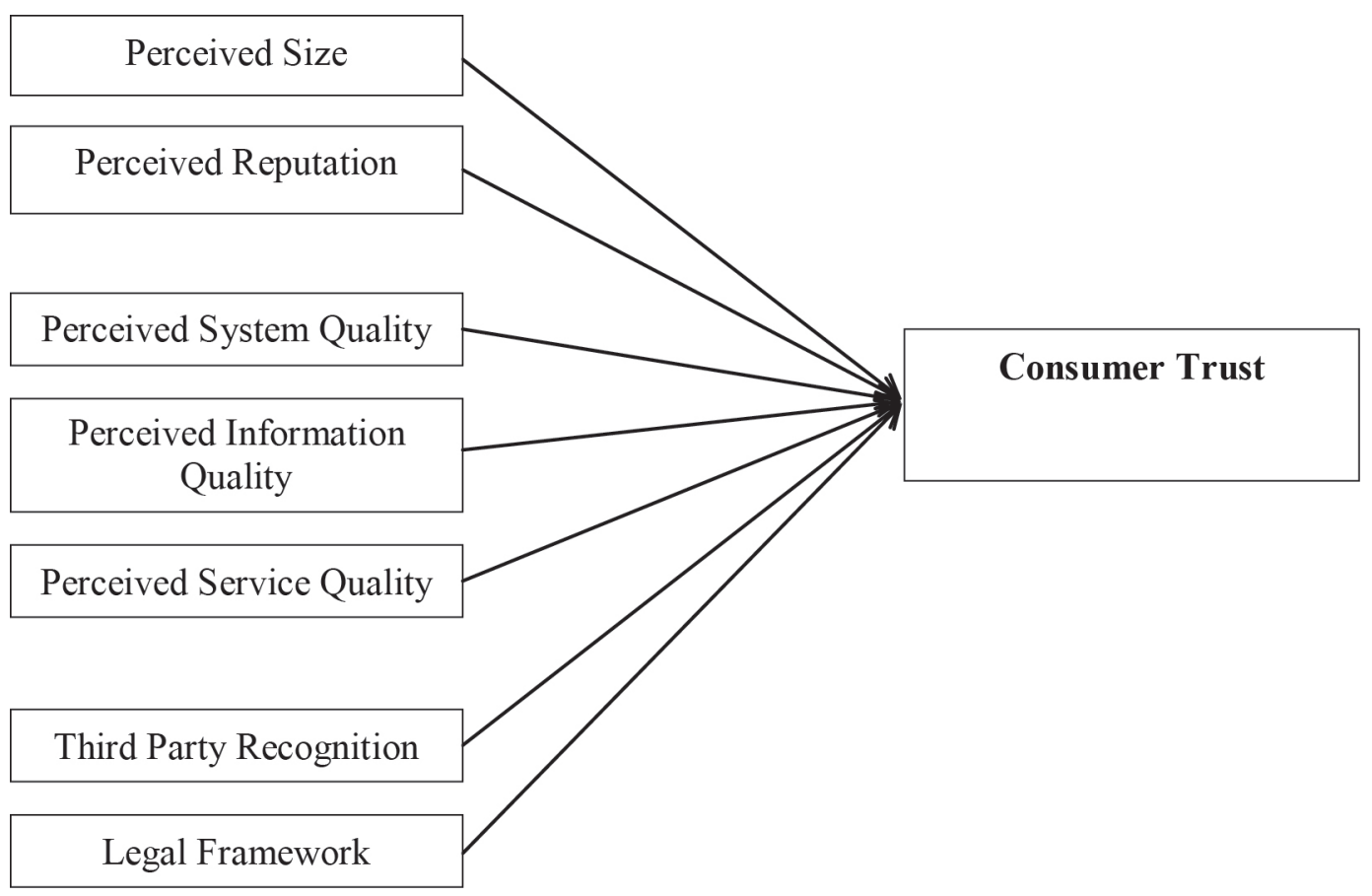

\section{METHODOLOGY}

\section{a) Sample and Data Collection}

The primary data in this research consists of data retrieved from a questionnaire, where knowledge about attitudes and behavior is obtained. The primary data were gathered using communication with the use of questionnaires. The target population is youths living in Ho Chi Minh City, almost are students, who have some knowledge of Internet shopping. In order to ensure the reliability of the responses, the online survey was created and sent to students via email and social network. By this way, the respondents are really internet users and then answer the questions more easily and reliably. The first part of the questionnaire includes screening questions to examine the suitability of the respondents to the research ("Have you ever visited an online shopping website?", "Have you ever purchased anything through the online shopping website?"). A total of 400 questionnaires have been distributed and 338 or $84 \%$ of them were returned by the respondents. Upon data screening process, 13 questionnaires were removed because the respondents do not have the 
online shopping experience and missing of information. Therefore, only 325 valid questionnaires are used during data analysis. Response rate is $81 \%$.

Of the 325 respondents, there is $55.4 \%$ of male and $44.6 \%$ of female. Moreover, the percentage of the respondents for age between 18-20, 21-23, 24-26, and older than 26 are $32.9 \%, 44 \%, 15.1 \%$, and $8 \%$, respectively, so most of the respondents in this study are at young age, under 23 years old (more than 60\%).

Also from the descriptive statistics of these samples, it can be found that most of the respondents have Internet surfing experiences for above six years $(60.6 \%)$ whereas the percentage of those having 3-6 years, 1-3 years, and under 1 year of Internet surfing experience are $27.1 \%$, $9.2 \%$, and $3.1 \%$, respectively. This is consistent with the fact that Internet has been popular since late 90's, and well developed about 10 years from now, and it is believed that the more familiar with using the Internet, the better the change for people to purchase through online stores or companies.

Table 1: Characteristics of Sample Demographics

\begin{tabular}{llll}
\hline Characteristics & & Frequency & Percentage (\%) \\
\hline Gender & Male & 180 & 55.4 \\
& Female & 145 & 44.6 \\
\hline Age & $18-20$ & 107 & 32.9 \\
\hline & $21-23$ & 143 & 44.0 \\
\hline \multirow{2}{*}{ surperience in Internet } & Under 1 year & 49 & 15.1 \\
& Over 26 & 26 & 8.00 \\
\hline & 10 -3 year & 30 & 3.1 \\
& 3-6 year & 88 & 9.2 \\
\hline & Over 6 year & 197 & 27.1 \\
\hline
\end{tabular}

\section{b) Measurement}

Questionnaires were designed according to the conceptual framework. The questionnaire is designed in Vietnamese and consisted of three major parts. After the first part of asking basic online shopping behavior to screen out those who haven't tried Internet shopping, the second part of the questionnaire is divided into eight sections measuring factors of forming customer trust (perceived company size, perceived company reputation, perceived system quality, perceived information quality, perceived service quality, third party recognition, legal framework and trust). A seven-point Likert scale is used in the questionnaire ranging from 1 being strongly disagree to 7 being strongly agree. The last part of the questionnaire is for demographic data collection including respondent's gender, age and Internet surfing experience.

\section{RESEARCH RESULT}

\section{Measurement}

a) Validity and Reliability of

Throughout the test, for the scales of perceived company size, perceived system quality, perceived information quality, third party recognition, consumer's trust in online company, and purchase intention, the reported Cronbach's alpha values ranged from 0.741 to 0.856 which were all higher than the acceptable 
reliability of 0.6 , meaning that these constructs have high reliability However, the researcher found that the alpha value of two constructs, including "perceived reputation" and "legal framework", was only 0.561 and 0.499 respectively and should not be accepted. Therefore, the "alpha if item deleted" and "corrected item-total correlation" were considered. For the construct of "perceived service quality", item SQ2 has the correlations less than 0.3. So, it needs to be eliminated.

After all, the new Cronbach's alpha of "perceived reputation" rose to 0.784 after the item of "This company has a reputation for being honest" was deleted. Similarly, the new Cronbach's alpha of "perceived service quality" increased to 0.794 after eliminating the item of "This website can be depended on to provide whatever is promised". Majority of the respondents choose "Undecided" for this statement since the service of online retailers in Vietnam is still limited at a certain level and it is very hard to ensure $100 \%$ that they always provides what they promise to the customers. In other words, this item seems to confuse the respondents. For the construct of legal framework, the researcher eliminated the item of "The existing legal framework is good enough to protect Internet shoppers" and the Cronbach's alpha rose up to 0.733 . Actually, e-commerce is still a new business model in Vietnam recently and thereby the legal framework for it is not really sufficient for protecting the customer's rights when they participate in the online transactions. Therefore, as the steady rate of adoption of e-commerce in Vietnam there are still many rooms for the government to improve the regulation system for this area. After that, all the items will be processed in the next steps of analyzing EFA and regression model. The Table 2 summarized the detailed reliability value for each constructs.

Table 2: Testing measurement scales by Cronbach's Alpha

\begin{tabular}{lcc}
\hline \multicolumn{1}{c}{ Factors } & $\begin{array}{c}\text { Number of } \\
\text { items }\end{array}$ & Cronbach's Alpha \\
\hline Perceived size (PS) & 3 & 0.741 \\
Perceived reputation (PR) & 3 & 0.784 \\
Perceived system quality (PSQ) & 7 & 0.833 \\
Perceived information quality (PIQ) & 7 & 0.856 \\
Perceived service quality (SQ) & 5 & 0.794 \\
Third party recognition (TPR) & 3 & 0.795 \\
Legal framework (LGF) & 2 & 0.733 \\
Customers' Trust (CT) & 5 & 0.784 \\
\hline
\end{tabular}

\section{b) Factor Analysis}

Factor analysis was made with all 30 variables grouped with extraction method of Principal Component Analysis and rotation method as Varimax with Kaiser Normalization. The results met all requirements with six factors extracted with 28 items (Table 3 ) 
Table 3: Factor Analysis

Rotated Component Matrixa

\begin{tabular}{|c|c|c|c|c|c|c|}
\hline \multirow{2}{*}{ Items } & \multicolumn{6}{|c|}{ Component } \\
\hline & 1 & 2 & 3 & 4 & 5 & 6 \\
\hline PRI The company is well-known & & & & .560 & & \\
\hline PR2 The company has a good reputation & & & & .617 & & \\
\hline $\begin{array}{l}\text { PR4 The company is known to be concerned about } \\
\text { customers }\end{array}$ & & & & .592 & & \\
\hline PSI The company is a very large company & & & & .689 & & \\
\hline $\begin{array}{l}\text { PS2 The company is one of the industry's biggest } \\
\text { suppliers on the Web }\end{array}$ & & & & .756 & & \\
\hline PS3 The company is a big player in the market & & & & .760 & & \\
\hline
\end{tabular}

PIQ1 The website has sufficient contents where I expect .798

to find information.

PIQ2 The website provides enough depth of information $\quad .788$

about its products

PIQ3 The website provides clear information for me to $\quad .761$

make a purchase

PIQ4 The website provides accurate information $\quad .774$

PIQ5 The website provides timely information $\quad .773$

PIQ6 The website provides reliable information $\quad .770$

SQ1 The website allows me to provide feedback about

.804

the website and products

SQ3 The website's security and privacy policies are

conspicuously displayed

SQ5 The website provides follow-up service to users

SQ6 The website anticipates and responds promptly to user needs and request

PSQ1 The website has fast response and transaction processing

PSQ2 The website has easy navigation to information

PSQ3 The website is easy to use .662

PSQ4 The website keeps personal information secure .688 from exposure

PSQ5 My interaction with this website is clear and understandable

PSQ6 The overall page layout is consistent throughout this website

PSQ7 The website creates an audio-visual experience

.675

TPRI There are many reputable third party certificate bodies available for assuring the trustworthiness of Internet vendors 


\begin{tabular}{|c|c|c|c|c|c|c|}
\hline \multirow{2}{*}{ Items } & \multicolumn{6}{|c|}{ Component } \\
\hline & 1 & 2 & 3 & 4 & 5 & 6 \\
\hline $\begin{array}{l}\text { TPR2 I think third party recognition bodies are doing a } \\
\text { good job }\end{array}$ & & & & & .851 & \\
\hline $\begin{array}{l}\text { TPR3 Existing third party recognition bodies are } \\
\text { adequate for the protection of Internet shoppers'interest }\end{array}$ & & & & & .782 & \\
\hline $\begin{array}{l}\text { LGF1 The existing business code of conduct is sufficient } \\
\text { for the protection of Internet shoppers" interest }\end{array}$ & & & & & & .852 \\
\hline $\begin{array}{l}\text { LGF2 The existing law is adequate for the protection of } \\
\text { Internet shoppers" interest }\end{array}$ & & & & & & .850 \\
\hline
\end{tabular}

Extraction Method: Principal Component Analysis.

Rotation Method: Varimax with Kaiser Normalization.

a. Rotation converged in 8 iterations.

From the result of factor analysis, Perceived Size and Perceived Reputation are grouped into a new factor named Store Reputation. The new hypotheses are as:

H1: Store reputation is positively related to Customer Trust on e-commerce websites.

H2: Perceived system quality is positively related to Customer Trust on e-commerce websites.

H3: Perceived information quality is positively related to Customer Trust on e-commerce websites.
H4: Perceived service quality is positively related to Customer Trust on e-commerce websites.

H5: The perceived effectiveness of third party recognition is positively related to Customer Trust on e-commerce websites.

H6: The perceived effectiveness of legal framework is positively related to Customer Trust on e-commerce websites.

c) Correlation and Regression Analysis 
Table 4: Correlation Test Result

\begin{tabular}{|c|c|c|c|c|c|c|c|}
\hline & $\begin{array}{c}\text { Store } \\
\text { Reputation }\end{array}$ & $\begin{array}{l}\text { Perceived } \\
\text { Information } \\
\text { Quality }\end{array}$ & $\begin{array}{c}\text { Perceived } \\
\text { Service } \\
\text { Quality }\end{array}$ & $\begin{array}{c}\text { Perceived } \\
\text { System } \\
\text { Quality }\end{array}$ & $\begin{array}{l}\text { Third-party } \\
\text { Recognition }\end{array}$ & $\begin{array}{c}\text { Legal } \\
\text { Framework }\end{array}$ & $\begin{array}{c}\text { Customer } \\
\text { Trust }\end{array}$ \\
\hline $\begin{array}{l}\text { Store } \\
\text { Reputation }\end{array}$ & 1 & & & & & & \\
\hline $\begin{array}{l}\text { Perceived } \\
\text { Information } \\
\text { Quality }\end{array}$ & $.204^{* *}$ & 1 & & & & & \\
\hline $\begin{array}{l}\text { Perceived } \\
\text { Service Quality }\end{array}$ & $.420^{* *}$ & .083 & 1 & & & & \\
\hline $\begin{array}{l}\text { Perceived } \\
\text { System Quality }\end{array}$ & $.198^{* *}$ & $.150^{* *}$ & $.234^{* *}$ & 1 & & & \\
\hline $\begin{array}{l}\text { Third-party } \\
\text { Recognition }\end{array}$ & $.238^{* *}$ & $.209^{* *}$ & $.198^{* *}$ & $.323^{* *}$ & 1 & & \\
\hline $\begin{array}{l}\text { Legal } \\
\text { Framework }\end{array}$ & -.076 & $-.163^{* *}$ & .060 & -.034 & -.030 & 1 & \\
\hline $\begin{array}{l}\text { Customer } \\
\text { Trust }\end{array}$ & $.478^{* *}$ & .055 & $.347^{* *}$ & $.325^{* *}$ & $.269^{* *}$ & .021 & 1 \\
\hline
\end{tabular}

The Pearson Correlation is applied Information Quality and Legal Framework to test the relationship among the 6 have no correlation with Customer Trust. independent variables and one dependent However, to further verify the relationship variable. The results of Pearson Correlation between Customer Trust and the six testing are presented in the Table 4 . The test attributes in a proper manner the research showed that Legal Framework has mostly continued with regression analysis. no correlation with others. Perceived

Table 5: Regression Analysis

\begin{tabular}{lccccc}
\hline \multicolumn{7}{c}{ Coefficients $^{\mathbf{a}}$} & & & \\
\cline { 1 - 3 } & \multicolumn{2}{c}{$\begin{array}{c}\text { Unstandardized } \\
\text { Coefficients }\end{array}$} & $\begin{array}{c}\text { Standardized } \\
\text { Coefficients }\end{array}$ & & \\
\cline { 2 - 4 } & $\mathbf{B}$ & Std. Error & Beta & $\mathbf{t}$ & Sig. \\
\cline { 2 - 3 } (Constant) & 2.378 & .371 & & 6.415 & .000 \\
Store Reputation & .313 & .043 & .381 & 7.204 & .000 \\
Perceived Information Quality & -.040 & .025 & -.079 & -1.612 & .108 \\
Perceived Service Quality & .085 & .036 & .123 & 2.350 & .019 \\
Perceived System Quality & .175 & .044 & .199 & 3.977 & .000 \\
Third-party Recognition & .072 & .034 & .108 & 2.129 & .034 \\
Legal Framework & .019 & .023 & .040 & .840 & .401 \\
\hline
\end{tabular}

a. Dependent Variable: Customer Trust 
The six independent variables explain $31.5 \%$ of variations in Customer Trust. From the correlation and regression analysis, the proposed hypothesis $\mathrm{H} 1$, $\mathrm{H} 2, \mathrm{H} 4$, and $\mathrm{H} 5$ are accepted. Store Reputation, Perceived Service Quality, Perceived System Quality and Thirdparty Recognition are positively related to Customer Trust. More discussion about this result would be mentioned in the next part.

On the other hand, Perceived Information Quality and Legal Framework have no relationship with Customer Trust $(\mathrm{p}>0.05)$. Therefore, hypothesis $\mathrm{H} 3$ and H6 are rejected. For the Legal Framework dimension, it seems that the customers do not even care of the regulations or rules when they are shopping online. From the survey, the respondents do not agree with the statement that "The existing legal framework is good enough to protect Internet shoppers". In fact, according the
Vietnam e-commerce report (2009), there are still many challenges in implementing the e-commerce laws and bringing them into reality. For the Perceived Information Quality, it could be because many people just use the e-commerce websites for making purchasing after they looked for information from other sources. Although information quality is important, in their mind, they cannot evaluate the reliability of information in sellers' websites. However, this explanation is not very clear and this result is one of limitations of the research that could be studied further in other researches.

Furthermore, Breusch-Pagan and Koenker test is used to test the homoscedasticity of residuals. The null hypothesis is that the residuals have equal variances across all levels of the variables. Table 6 shows that the $p$ values are greater than .05 , so it can be said that the assumption of homoscedasticity is satisfied.

Table 6: Homoscedasticity Test

Breusch-Pagan test for Heteroscedasticity (CHI-SQUARE df=P)

Significance level of Chi-square $\mathrm{df}=\mathrm{P}$ (H0:homoscedasticity)

One of the assumptions of linear regression analysis is that the residuals are normally distributed. The normal Q-Q plot is used to test the normality of the residuals.
Based on Figure 2, the residuals from this regression appear to conform to the assumption of being normally distributed. 
Figure 2: Normal Q-Q Plot of Standardized Residual

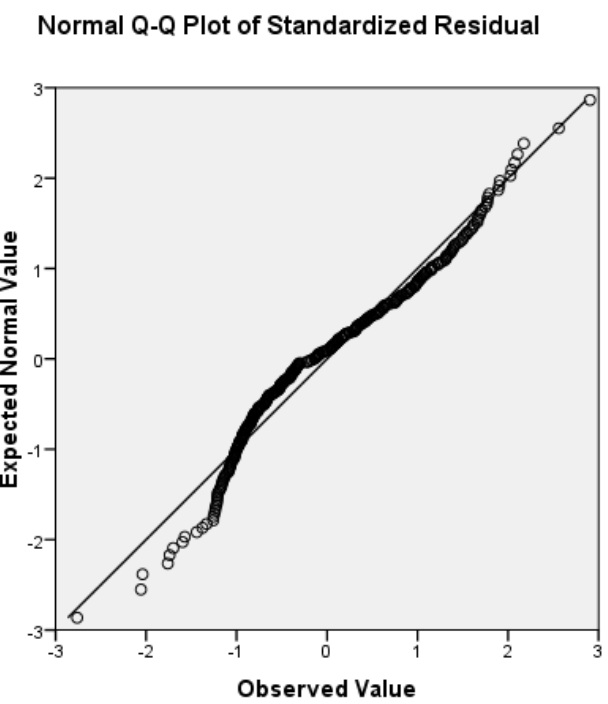

\section{RECOMMENDATION}

This study's findings have some implications for managers and developers of virtual stores as well as for business initiating or currently conducting B2C e-commerce. Even though this study is conducted on youths, they are potential buyers and wisely understanding the criteria for a good online retailer that makes them feel confident in the decision of purchasing products or services online. Obviously, the importance of trust in future purchase intention indicates that trust is a criterion consumer use to evaluate sellers on the Internet. Therefore, it is crucial for online vendors to attract potential customers to make purchases by increasing their trust. This study provides insights into how trust is built by identifying three groups of antecedents of consumer trust.

Firstly, a more positive perception of trust can be achieved by attempting to widen the company size in in term of market share, distribution network, as well as capacity; developing and communicating reputation. Reputation plays the most important role in building initial trust in the vendor because a new user with no experience in the site can rely on the experience of others as reflected in reputation. Therefore, it is suggested that retailers should have a clear vision and long-term strategy in building a good image. If retailers focus too much on the financial aspect or short-term benefits and do not meet the customers' expectations about the products or services quality, there will be a negative impact on their business in the future. In fact, words of mouth play a very important role in the success of any kinds of business, B2C e-commerce model is not an exception. Moreover, marketing activities are indispensable in order to enhance the brand image, such as advertising, participating public activities (sponsor, scholarship, charity, etc).

Secondly, building a website with good system quality and good service quality is necessary due to the lack of faceto-face interaction. If customers find an online company to be difficult to navigate or use in transactions, poor customer service, they will move to competitor sites and may not go back any more. The result of questionnaire survey has shown some ways companies can make a website more useful and therefore increase their trustworthiness. The online company should have a customer care center or 24/24 hot-line which serves the customers' questions promptly as well as providing 
necessary guidelines. Moreover, aftersale services, such as warranty, feedback, e-mailing at each stage purchasing stage, are also very important. The website should be easy to use without complex navigation schemes and disorganized layouts. In other words, a user-friendly website is believed to be more reliable and professional in the eyes of customers. In addition, the system also needs to be fast in processing and highly secured in browsers, in account and transaction security. As mentioned earlier, majority of Vietnamese customers think it is unsafe to buy things via the Internet as they have to provide their financial information on the website in order to make a payment.

Thirdly, earning the approval of reputable and credible third parties or certificate of quality assurance will make the website be more professional and trustworthy. For example, Trustvn reliable e-commerce website is a program which has been approved by the Ministry of Industry and Trading several years ago. In order to achieve the Trustvn seal in the website, the website needs to follow specific criteria in order to protect the highest interests of consumer, such as policy of protecting customer"s information, dispute resolution, responsibility of providing commitment and regulation to the customer before implementing the transaction and so on. Besides, online enterprises can also purchase services from the reliable third parties for protecting their websites. Verisign certificate is one of the most reliable third party organizations in the world, which helps to secure the website from malware, virus as well as increasing the response speed of the website and so on. In Vietnam, Nguyen Kim is one of the companies which have purchased the Verisign services for building a highlysecured and fast response website. Finally, both online vendors and trusted third-party referees need to work together to help increase the visibility and awareness of that seals of approval.

\section{CONCLUSION}

The purpose of this study is to identify the factors influencing consumers' trust in the context of $\mathrm{B} 2 \mathrm{C}$ e-commerce from the youths' perspective in Ho Chi Minh City. Through the extensive literature review, the researcher has found out the three groups of factors which have been examined by many researches in different countries about their impact on the consumers' trust in online company. This study has examined the impact of customers' perceptions about the company, customers' perceptions about the website quality (including perceived service quality and perceived system quality), and third party recognition on the consumers' trust in online company. Although this study provides the significant insights to consumers' trust in online company, further study should cover a larger group and wide areas in the survey. This may include working adults from different geographical areas in Vietnam. Working adults are also huge potential online customers since they have a steady income and they may not have time for shopping at physical stores. Besides, although the scales used for measuring constructs of this study are adapted from previous studies, further research might consider developing more elaborate measures to allow for a richer coverage of construct scales and more appropriate in the Vietnamese context. 


\section{REFERENCES}

Aladwani, A., and Palvia, P., 2002. Developing and Validating an Instrument for Measuring User Perceived Web Quality. Information and Management. Vol. 39.

Abdullah, Y. and Ceren, G.A. (2009). A Theoretical Analyze on the Concept of Trust in Organizational Life. European Journal of Social Science. Vol. 8(2).

Barnes, S.J., and Vidgen, R. (2001). An Evaluation of Cyber-bookshops: The WebQual Method. Internation Journal of Electronic Commerce. Vol. 6, pp. 11-30.

Chanidapa, P., Nattapong, S., Sirion, C., and Howard, C. (2012). The Factors Influencing Consumer Trust of Internet Shopping in Thailand. International Journal of Electronic Commerce. Vol. 19.

Chen, Y.H., and Barnes, S. (2007). Initial Trust and Online Buyer Behavior. Industrial Management + Data System. Vol. 107

Cheskin Research and Studio Archetype/Sapient (1999). eCommerce Trust Study.

Cheung, C., and Lee, M. (2000). Trust in Internet Shopping: A proposed Model and Measurement Instrument, in Proceedings of the 2000 Americas Conference on Information Systems (AMCIS).

Cooper, D. R. and Schindler, P. S. (2006) Business Research Methods, 8 ed., The US: McGraw-Hill Companies, Inc.

Corritone et al. (2003). Online Trust: Concepts, Evolving Themes, A Model. International Journal of Human-Computer Studies. Vol. 58(6), pp. 737-758.

Das, T.K. (1998). Between trust and control. Developing confidence in partner cooperation in alliances. The Academy of Management Review. pp. 491-513.

Dayal et al. (1999). How to build trust online. Journal of Marketing Management. Vol. 19, pp. 9-30.

DeLone, W.H., and McLean, E.R. (2003). The DeLone and McLean Model of Information System Success: A Ten-year Update. Journal of Management Information System. Vol. 19, pp. 9-30.

Denzin, N. K. \& Lincoln, Y. S. (1994). Introduction: Entering the field of qualitative research. In N. K. Denzin \& Y. S. Lincoln. (eds.). Handbook of qualitative research. Thousand Oaks, CA: Sage.

Ding, M. (2010). A Study of Consumer Trust in Internet Shopping And the Moderating Effect of Risk Aversion in Mainland Chian. (Master"s thesis). Retrieved from ProQuest Dissertations and Theses.

Doney, P.M., and Cannon, J.P., (1997). An Examination of the Nature of Trust in BuyerSeller Relationships". Journal of Marketing. Vol.61, pp. 35-51.

Dwyer, R.F., Schurr, P.H., and Oh, S. Output Sector Munificence Effects on the Internal Political Economy of Marketing Channels. Journal of Marketing Research (24), pp. 347-358.

E-Asian Task Force. (2003). E-commerce and E-business. Retrieved from http://www. eprimers.org

Fatah et al. (2011). Factors affecting the attitude of trust in Internet purchasing from the perspective of consumers.

Fogg, B.J. (2002). Stanford guidelines for web credibility. A research summary from the 
Stanford Persuasive Technology Lab.

Greenspan, R. (2002). Seals of Approval. eCommerce Guide, June 6.

Habibur, R., and Lili, H. (2011). Customer Satisfaction in E-Commerce: A Case Study of China and Bangladesh. (Master"s thesis). Retrieved from ProQuest Dissertations and Theses.

Heijden, H., Verhagen, T., and Creemers, M. (2000). Predicting Online Purchase Behavior: Replications and Tests of Competing Models.

Jarvenpaa, S.L., Tractinsky, N., and Vitale, M. (2000). Consumer Trust in an Internet Store. Information Technology and Management. Vol. 1, pp. 45-71.

Kelly, P.G.W. (1997). Are You Ready for "Trust" Economy? Computer World. Vol. 31.

Koufaris, M., and Hampton-Sosa, W. (2004). The Development of Initial Trust in an Online Company by New Customers. Information \& management. Vol. 41, pp. 377- 397.

Koufaris, M., Kambil, A., and Labarbera, P. (2001). Consumer Behavior in Web-based commerce: an empirical study. International Journal of Electronic Commerce. Vol. 6, pp. 115-138.

Kim, S., and Stoel, L. (2004). Apparel retailers: Website Quality Dimensions and Satisfaction. Journal of Retail and Consumer Service. Vol. 11.

Kim, H., Xu, Y., and Koh, J. (2004). A Comparison of Online Trust Building Factors between Potential Customers and Repeat Customers. Journal of Association for Information Systems. Vol. 5

Lee, M.K.O., and Turban, E. (2001). A Trust Model for Consumer Internet Shopping. International Journal of Electronic Commerce. Vol. 6(1), pp. 75-91.

Lewicki, R.J., and Bunker, B.B. (1996). Developing and Maintaining Trust in Work Relationships. The Academy of Management Review. Vol. 23(3).

Lewis, D.J., and A. Weigert. (1985). Trust as a social reality. Social Forces 63 (4): 96785.

Liang, T.P., and Lai, H.J. (2002). Effect of Store Design on Consumer Purchases: An Empirical Study of on-line Bookstores. Information and Management. Vol. 39.

Liu, C., and Arnett, K.P. (2000). Exploring the Factor Associated with Web Site Success in the Context of Electronic Commerce. Information and Management. Vol. 38, pp. 23-33.

Mayer, R.C., David, J.H. and Schoorman, F.D. (1995). An Integrative Model of Organizational Trust. Academy of Management Review. Vol. 20.

McKnight, D.H., Choudhury, V., and Kacmar, C. (2002). The impact of Initial Consumer Trust on Intention to Transact with a Web Site: A Trust Building Model. Journal of Strategic Information Systems. Vol. 11, pp. 297-323.

McKnight, D.H., Cummings L.L., and Chervany, N.L. (1998). Initial trust formation in new organizational relationships. Academy of Management Review. Vol. 23, pp. 473- 490.

Njite, D., and Parsa, H.G. (2005). Structural Equation Modeling of Factors that Influence Consumer Internet Purchase Intentions of Services. Journal of Service Research. Vol. 5(1), pp. 43-59. 
OECD (1999). Economic and Social Impact of E-commerce: Preliminary Findings and Research Agenda. OECD Digital Economy Papers. No. 40. OECD Publishing.

Parasuraman, Z., Zeithaml, V.A., and Berry, L.L. (1988). Servqual: A Multiple-item Scale for Measuring Consumer Perceptions of Service Quality. Journal of Retailing. Vol. 64, pp. 12-40.

Princeton Survey Research Associates (2002). A matter of trust: What users want from web sites. Results of a national survey of Internet users for Consumer WebWatch.

Park, C.H. and Kim, Y.G. (2003). Identifying Key Factors Affecting Consumer Purchase Behavior in an Online Shopping Context. International Journal of Retail and Distribution Management. Vol.31, pp. 16-29.

Rechheld, F. F. \& Schefter, F. (2000). E-Loyalty: Your Secret Weapon on the Web, Harvard Business Review. 78 (July-August). 105-113.

Rousseau, D.M., Sitkin, S.B., Burt, R.S., and Camerer, C. (1998). Not so different after all: A cross-discipline view of trust. Academy of Management Review. Vol. 23.

Schurr, P.H. and J.L. Ozanne. Influence on Exchange Processes: Buyer"s Preconceptions of a Seller"s Trustworthiness and Bargaining Toughness. Journal of Consumer Research. Vol. 11, pp. 939-953.

Slater, S. (1995). Issues in Conducting Marketing Strategy Research. Journal of Strategic Marketing. Vol. 3, pp. 257-270.

Tabachnick, B.G. and Fidell, L.S. (2001). Using Multivariate Statistics, $4^{\text {th }}$ ed. Allyn Bacon, Pearson Education Company.

Teo T.SH., and Liu J. (2007). Consumer Trust in E-commerce in the United States, Singapore and China. Omega, pp. 22-38.

Tony, A., Seewon, R., and Ingoo, H. (2007). The Impact of Web Quality and Playfulness on User Acceptance of Online Retailing. Information and Management. Vol. 44(3).

US Department of Commerce Industry Report. (2009). Retrieve from: http://trade.gov/ td/ocg/report08 processedfoods.pdf 78

Vietnam E-commerce Report. (2009). Retrieve from: http://www.moit.gov.vn/vsi portlets/UserFiles/Docman/Upload/Vietnam\%20e-commerce\% 20report $\% 20$ 2009.PDF

Vietnam NetCitizen Report. (2011). Internet Usage and Development in Vietnam. Retrieve from http://techblog.ad.zing.vn/wp-content/uploads/2012/04/Cimigo NetCitizens-2012.pdf

Vinacorp Retailing Report. (2011). Retrieve from http://www.vinacorp.vn/market/phantich-nganh/dich-vu-tieu-dung/ BranchReport\%5C04042011\%5CRetailingRepo rt-04042011.pdf

Yin, R. (1994). Case Study Research: Design and Methods (2nd edition). Thousand Oaks. CA: Sage Publications.

Yoon, S. (2002). The Antecedents and Consequences of Trust in Online Purchase Decision. Journal of Interactive Marketing. Vol. 16(2), pp. 47-63.

Young, H.K., Dan, J.K. (2003). The Impact of Culture Differences on Trust in Ecommerce. Research Report.

Wakefield, R.L. and Whitten, D. (2006). Examining User Perceptions of Third Party 
Organizations Credibility and Trust in an E-Retailer. Journal of Organizational and End User Computing. Vol. 18

Wang, Y. (2008), Assessing e-commerce systems success: A respecification and validation of the DeLone and McLean model of IS success, Information Systems Journal, Volume 18, pages 529-557.

Webb, C. (1992). The use of the first person in academic writing: objectivity, language and gatekeeping. Journal of Advanced Nursing. Volume 17, pp 747-752.

Wrightsman, L.S. Interpersonal trust and attitudes toward human nature. In J.P. Robinson, P.R. Shaver, and L.S. Wrightsman (eds.), Measures of Personality and Social Psychological Attitudes, vol. 1. San Diego: Academic Press, 1991, pp. 373-412.

Zeithaml et al. (2002). Service Quality Delivery through Web Sites: A Critical Review of Extent Knowledge. Journal of the Academic of Marketing Science. Vol. 30, pp. 362-375.

Zhang, P., and Dran, G.M. (2002). User Expectations and Rankings of Quality Factors in Different Web Site Domains. International Journal of Electronic Commerce. Vol. 6(2).

Zwass, V. (1996). Electronic Commerce: Structures and Issues. International Journal of Electronic Commerce. Vol. 1(1), pp. 3-23. 